\title{
Evaluating solid waste landfill site selection using multi-criteria decision analysis and geographic information systems in the city of Elazı $\breve{g}$, Turkey
}

\section{Elazığ ilinde çok kriterli karar verme analizi ve coğrafi bilgi sistemleri kullanılarak katı atık depolama sahası seçiminin değerlendirilımesi}

\author{
Murat ÇELIKER ${ }^{1}$, Osman YILDIZ2², Nilüfer NACAR KOÇER ${ }^{3}$ \\ ${ }^{1}$ General Directory of State Hydraulics Works, $9^{\text {th }}$ Regional Directory, Elazığ, Turkey. \\ mceliker23@gmail.com \\ 2Department of Civil Engineering, Faculty of Engineering, Kırıkkale University, Kırıkkale, Turkey. \\ osmanyildiz@kku.edu.tr \\ 3Department of Environmental Engineering, Faculty of Engineering, Firat University, Elazığ, Turkey. \\ nkocer@firat.edu.tr
}

Received/Geliş Tarihi: 30.03.2018, Accepted/Kabul Tarihi: 13.09.2018

doi: $10.5505 /$ pajes.2018.70493

* Corresponding author/Yazışıllan Yazar

Research Article/Arastırma Makalesi

\section{Abstract}

Solid waste landfill site selection is a relatively complex process and depends on several criteria and official regulations. In this study, the suitability of solid waste landfill site selection for the city of Elaziğ, Turkey, was determined by Multi-Criteria Decision Analysis (MCDA) and Geographic Information Systems (GIS). For this purpose, nine different criteria, namely distance from residential areas, distance from roads, distance from rivers, distance from spring wells, geology, slope, aspect, land capability classification and land use, were taken into consideration and their degrees of relative importance were defined via MCDA and the schematic maps for each criterion were prepared with GIS applications. The final landfill site suitability map for the study area was obtained by the overlay analysis tool of ArcGIS 9.3. The study results reveal that the landfill suitability index values for the selected site range between 2.64 and 6.10. The major part of the landfill site has relatively low index values implying that the selected site is suitable for solid waste landfill.

Keywords: Solid waste landfill site, multi-criteria decision, Landfill site suitability index, Geographic information systems, Analytic hierarchy process, Elazığ.

\section{Introduction}

The disposal of domestic solid wastes in sanitary landfills is handled as the most economical solution in many developing countries. Therefore, the selection of a suitable landfill site for this purpose emerges as a major issue in solid waste management. Actually, this is a relatively complex and exhausting process that requires consideration of several social, environmental, technical and economic factors. Due to the possibility of effecting biophysical and ecological systems, the environmental factors for disposing solid wastes have become a more important issue [1],[2]. In this regard, a sanitary landfill site should not basically cause the pollution of soil, surface and subsurface water resources [3]. The landfill site selection process for waste disposal should follow certain official laws and regulations, which usually include various complex requirements. However, this can be overcome with the use of GIS techniques [4],[5]. The integration of GIS and Analytical Hierarchy Process (AHP) is an effective tool for the solution of solid waste site selection problems [6]-[11].

Various analysis methods for solid waste landfill site selection are presented in the literature. MCDA is among the most widely
Öz

Katı atık depolama sahası seçimi nispeten karmașık bir süreçtir ve çeșitli kriterlere ve resmi düzenlemelere bağlıdır. Bu çalıșmada, Elazığ ilinde için katı atık depolama sahası seçiminin uygunluğu, Cok Ölçütlü Karar Analizi (ÇÖKA) ve Coğrafi Bilgi Sistemleri (CBS) ile belirlenmiștir. Bu amaçla, yerleșim alanlarına uzaklık, yollara uzaklık, akarsulardan uzaklık, kaynak suyu kuyularından uzaklık, jeoloji, eğim, bakl, arazi kapasite sınıflandırması ve arazi kullanımı olmak üzere dokuz farklı kriter göz önünde bulundurulurak CÖKA ile göreli önem dereceleri tanımlanmış ve her bir kriter için șematik haritalar CBS uygulamaları ile hazırlanmıștır. Calıșma alanı için son depolama sahası uygunluk haritası, ArcGIS 9.3'ün yer paylaşımı analiz aracı ile elde edilmiştir. Calıșma sonuçları, seçilen saha için dolgu uygunluk indeksi değerlerinin 2.64 ile 6.10 arasında olduğunu ortaya koymuştur. Depolama sahasının önemli bir kısmı, seçilen alanın katı atık düzenli depolama için uygun olduğunu ima eden nispeten düşük endeks değerlerine sahiptir.

Anahtar Kelimeler: Katı atık depolama sahası, Çok ölçütlü karar, Depolama sahası uygunluk endeksi, Coğrafi bilgi sistemleri, Analitik hiyerarși süreci, Elazı̆̆. used methods for this purpose [2],[4],[5],[12]. The main principle in this method is to divide the problem into smaller and meaningful parts, and then integrate them in a logical sequence [13]-[15]. For site selection problems, data processing and their effective presentation are managed by GIS, while arrangements of alternatives and potential results are realized through MCDA based on subjective values and priorities [5],[16],[17].

This study presents an investigation of the suitability of site selection for solid waste landfill in the city of Elazı̆g, Turkey, by MCDA and GIS tools. Actually, the first phase of the solid waste project was developed in 2008.

\section{Study area description}

The site is about $28 \mathrm{~km}$ away from the city centre with about 130 ha total surface area located around the villages of Dișidi, Çöteli and Üçağaç (Figure 1). The study area is digitized with the use of 1:25.000 $(1 \mathrm{~cm}=250 \mathrm{~m})$ scaled maps and it is assigned UTM projection (zone 37) with ED50 datum. The project life is 30 years and about $60 \%$ of the site is planned to be utilized for waste disposal. 


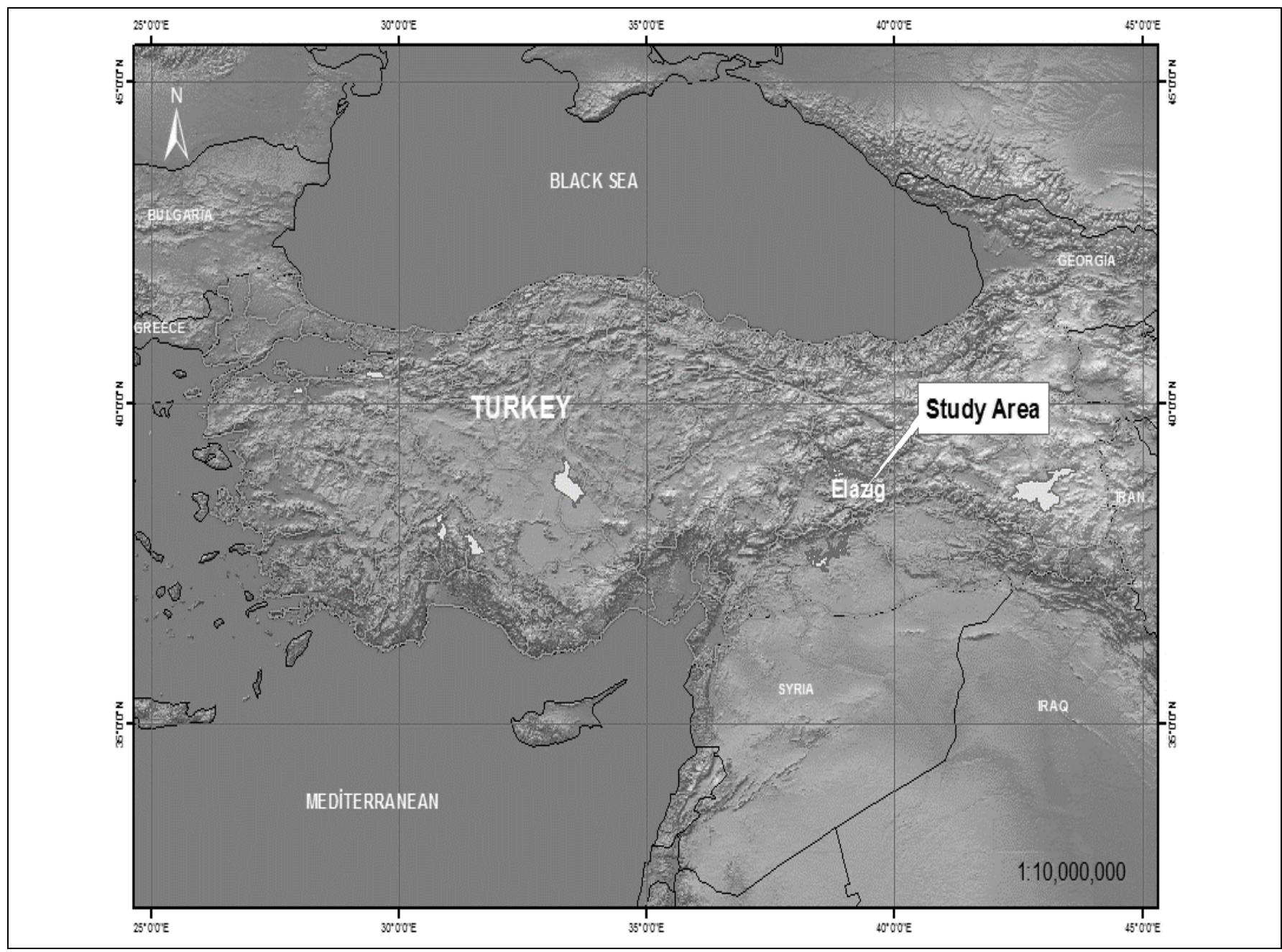

Figure 1: The municipal solid waste landfill site for the city of Elazığ.

The average density of the solid waste is estimated as $0.542 \mathrm{ton} / \mathrm{m}^{3}$ and the municipal waste for the city is about 350 tons per day [18]. The content of the domestic wastes varies locally and seasonally. It consists of about 38\% organic materials and the rest is paper, cardboard, textile, plastic, leather, metal, wood, glass, ash and other materials. The wastes are collected together at their source and dumped in landfills at the waste site [19].

\section{Materials and method}

In this study, the methodology for determining suitable landfill site for waste disposal with MCDA and GIS tools is summarized as follows;

- Conducting field survey for visual inspection,

- Collecting up-to-date data from relevant databases for the study area,

- Determining criteria in accordance with the laws and regulations,

- Detecting contribution of criteria and generating decision making matrix for AHP,

- $\quad$ and realizing a spatial clustering process in GIS for finding the most suitable area.
Basically, waste disposal site selection carried out by GIS is based on immediate exclusion of improper fields and weighting the remaining area accordingly [7],[20]-[22]. Here, delineation of buffer zones, distance and layer analyses were carried out by ArcGIS 9.3 using raster data. The raster map layers created with GIS were evaluated by MCDA. They were overlaid and combined together with the use of weighted linear combination method which is also named as scoring method or simple additive weighting [16],[23],[24].

In this study, a total of nine criteria, namely distance from residential areas, distance from roads, distance from rivers, distance from groundwater wells, geology, slope, aspect, land classification and land use are taken into consideration for the solid waste storage area suitability analysis. The selection of criterion was handled in accordance with the official laws and regulations on municipal waste disposal. The similar literature was also taken into consideration when selecting the criteria which may have various environmental impact.

The spatial data for the criteria used in this study were obtained from the up-to-date database resources of the General Directorate of State Hydraulic Works (DSi), the General Directorate of Mineral Research and Exploration (MTA), and the Ministry of Forestry and Water Management. 
Each criterion determined for the landfill site selection does not have equal importance. Therefore, their normalized weighting values and the sub-criterion grading points should be assigned in order to estimate landfill suitability index (LSI). The appointed criterion weights can vary according to the characteristics of working area [18].

As defined by Eq. 1, LSI is a multiplication product of the criterion normalized weighting index $\left(\mathrm{K}_{\mathrm{a}}\right)$ and the sub-criterion grading index $\left(\mathrm{K}_{\mathrm{p}}\right)$.

$$
\mathrm{LSI}=\sum\left(\mathrm{K}_{\mathrm{a}} \cdot \mathrm{K}_{\mathrm{p}}\right)
$$

The grading points of sub-criteria range from 0 to 10 . The normalized weighting values of a criterion is specified according to its relative importance using AHP. Developed by Thomas H. Saaty in 1977, AHP is an effective tool for dealing with complex decision making and can help decision makers prioritize and make the best decision. By reducing complex decisions to a set of pairwise comparisons and synthesizing the results, the AHP helps to capture both subjective and objective aspects of a decision. Also, it uses a useful technique to check the consistency of the evaluator's assessments, thereby reducing the bias in the decision-making process [6],[7],[25],[26]. It has three main features including;

i. Hierarchical presentation and discretization (i.e., dividing the problem into lower segments in its hierarchical structure),

ii. Differentiation and combination according to priorities (i.e., sorting the parts according to their relative importance), and

iii. Logical consistency (i.e., parts should be grouped rationally and arranged consistently according to a logical criterion). In AHP, grading, assignment of relative importance and weighting of selected criteria should be carried out carefully [27],[28]. In the literature, AHP was effectively utilized for waste storage site selection based on different criteria [6],[7],[26].

The relative importance of selected criteria for waste disposal site selection is determined according to the Saaty scaling given in Table 1. This enables one to estimate the relative contribution of each criterion independently [17],[29],[30].

Table 1: The Saaty scaling table for analytical hierarchy process.

\begin{tabular}{cc}
\hline Definition & Degree of Importance \\
\hline Equal Importance & 1 \\
Fair Degree Importance & 3 \\
High Degree Importance & 5 \\
Very High Degree Importance & 7 \\
Extreme Importance & 9 \\
\hline
\end{tabular}

Probable errors should be tested and consistency should be measured when weightings are graded according to the selected criteria. A consistency ratio (CR) is estimated to indicate the objectivity of normalized weighting values (Eq. 2).

$$
\mathrm{CR}=\mathrm{CI} / \mathrm{RI}
$$

where $\mathrm{CI}$ represents consistency index and RI refers to random index. CI is defined by Eq. 3 as follows;

$$
\mathrm{CI}=\left(\lambda_{\text {maks }}-\mathrm{n}\right) /(\mathrm{n}-1)
$$

in which $\lambda_{\text {maks }}$ is the maximum eigenvalue and $n$ is the matrix dimension. An intercomparison matrix can be consistent if its $\lambda_{\text {maks }}$ is equal to the matrix dimension [25]. Here, $\lambda_{\text {maks }}$ is the arithmetic mean of a new matrix constituted by dividing each element of another matrix, which is obtained by multiplying normalized weighting values from intercomparison, into its actual value normalized previously. The variation of RI values with the matrix dimension is given in Table 2, where it is seen that RI tends to increase with the matrix dimension.

In order to have a consistent decision matrix, CR should be normally less than 0.1 . If it gets close to zero, the intercomparison results become valid [23]-[25].

In this study, distance from residential areas, distance from roads, distance from rivers, distance from spring wells, geology, slope, aspect, land classification and land use were taken into consideration as main criteria for determining a suitable solid

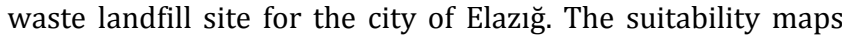
were created via GIS tools for each criterion determined within the scope of this work. Later, the final suitability map was obtained by combining the individual maps. The buffer zones and scores of the sub-criteria were taken from Table 3 . A more detailed discussion for individual criterion is given in the following paragraphs.

\subsection{Distance from residential areas}

Solid waste storages constructed within or near residential areas may cause various environmental problems such as water and soil pollution, low air quality, heavy smell, noise etc. According to the Turkish Regulation of Solid Waste Disposal in Sanitary Landfills, solid waste storages cannot be constructed at places less than $1000 \mathrm{~m}$ away from residential areas [31]. In addition, in the literature, an urban waste storage should be within $10-25 \mathrm{~km}$ so that it can be accessible every season and transportation costs can be optimized [4]. The distance between the solid waste storage site selected for Elazığ and residential areas was classified in Figure 2 with the use of GIS tools, which utilized the sub-criteria score information in Table 3 . The scores were actually determined by following the national regulation rules, the relevant literature and the development and distribution characteristics of residential areas. As the map shows the selected site seems to be suitable for solid waste storage purposes.

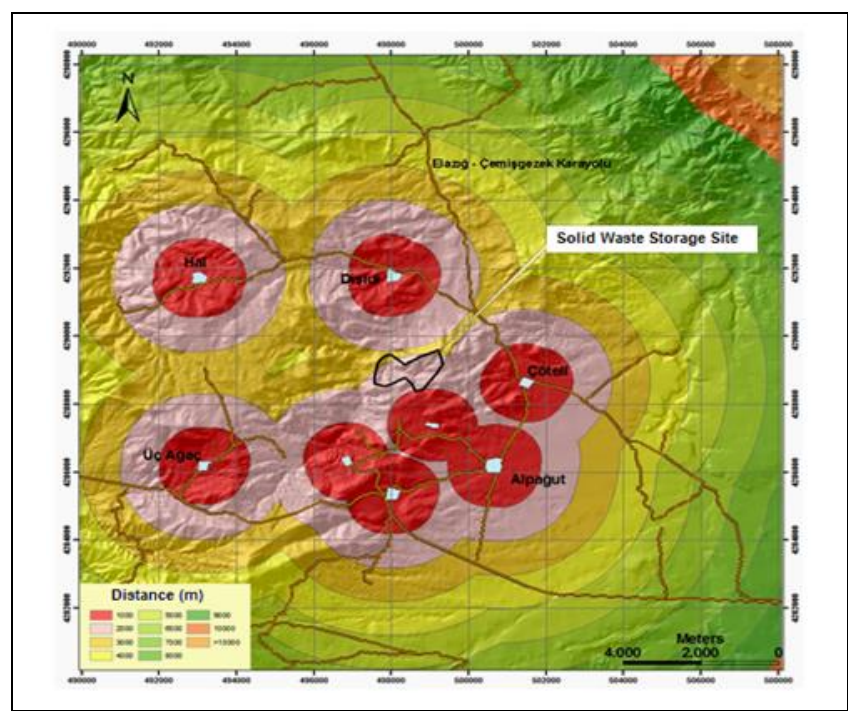

Figure 2: The spatial map for distance from residential areas. 
Table 2: Variation of RI values with matrix dimension.

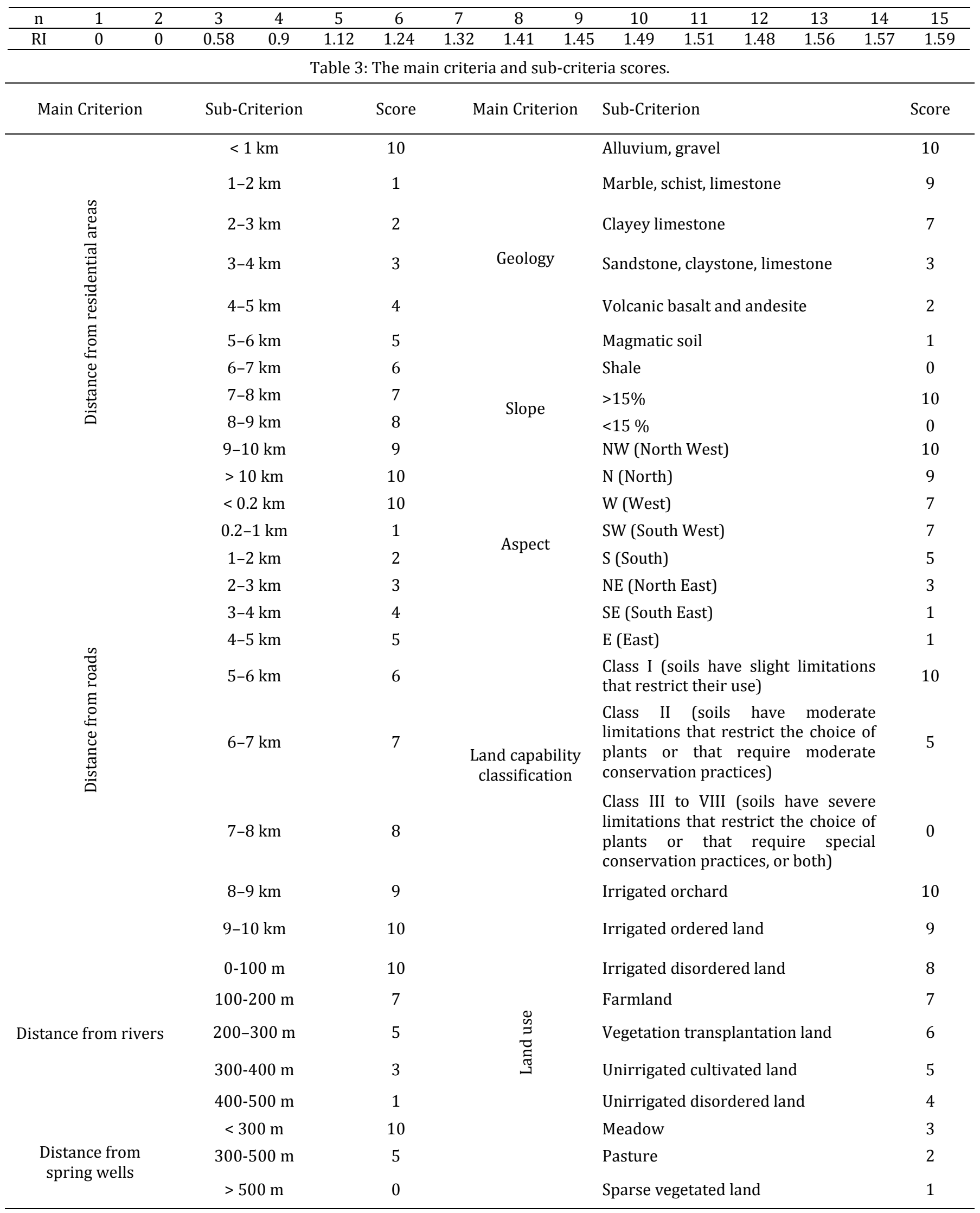




\subsection{Distance from roads}

There are two main transportation lines within the study area, namely the Elazığ-Tunceli Çemişgezek state highway and the Dişidi-Çöteli-Üçağaç village road. The storage facility should not be very far from roads and it should be accessible under all seasonal conditions [3],[12]. The distance between the solid waste storage site and residential areas was classified in Figure 3 with the use of GIS tools according to the score values in Table 3. The figure indicates that the selected area seems to be not far away from roads and meets the accessibility criteria.

\subsection{Distance from rivers}

The Regulation for Sanitary Disposal of Wastes requires that waste storage facilities cannot be constructed near protected zones of surface waters to be utilized for public usage [33]. A number of studies exists in the literature about site selection or waste storage in places close to water resources with possible flood risks [20],[22],[34]. The digital elevation model (DEM) of the study area was produced through ArcGIS software from 1:25.000 scaled topographical maps. Later, the drainage patterns of the area were obtained and the stream distance layer was formed by employing the Euclid distance module with the weighting values in Table 3. As shown in Figure 4, the selected site is found not suitable for solid waste storage because of relatively high flood risks.

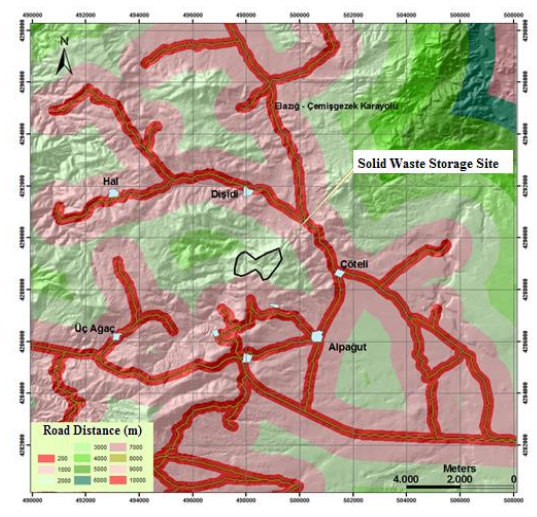

Figure 3: The spatial map for distance from roads.

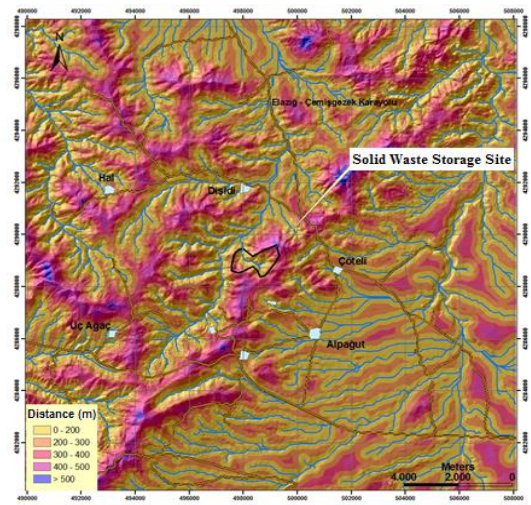

Figure 4: The spatial map for distance from rivers.

\subsection{Distance from groundwater wells}

As indicated in the literature and ordered by the relevant official regulations, solid waste storages cannot be located in places close to groundwater aquifers and springs. Solid wastes may contain liquids and gases which can be harmful to groundwater resources [35]. Therefore, it is recommended in the literature that the minimum distance between solid waste storages and underground waters and/or wells should be between 300 and $500 \mathrm{~m}$. Figure 5 displays the classification map for the distance from groundwater wells obtained in GIS environment by the Euclid distance module. Here, the selected waste storage site seems to be far enough from groundwater wells.

\subsection{Geology}

The geological map of the waste disposal area was constructed from 1:25.000 scale geological maps prepared by the Turkish General Directorate of Mineral Research and Exploration as shown in Figure 6. The study area contains recrystallized limestones and gravels of Keban metamorphics, gabbro of Elazığ magmatic fromations, granodiorites, plutonic rocks such as granites, sandstones of Kırkgeçit formation, alternated claystones and limestones flysches, and basaltic and andesitic rocks of Karabakır formation. They were classified according to their hydraulic permeability as in Table 3. As shown in Figure 6 , the study area has limestone units that may involve rich groundwater resources. Therefore, the selected site seems to be not convenient for solid waste storing geologically.

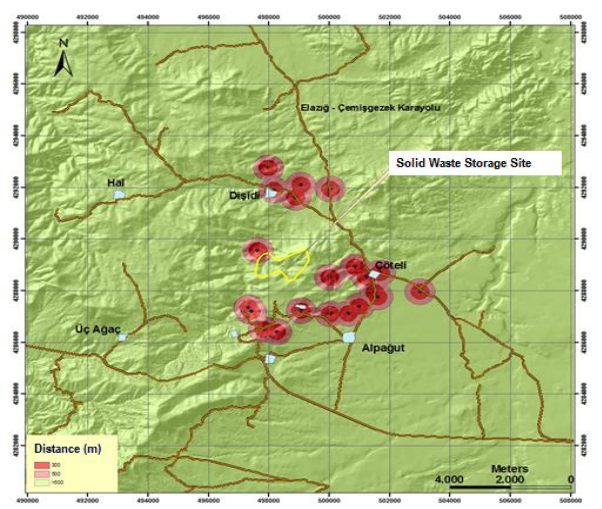

Figure 5: The spatial map for distance from groundwater wells.

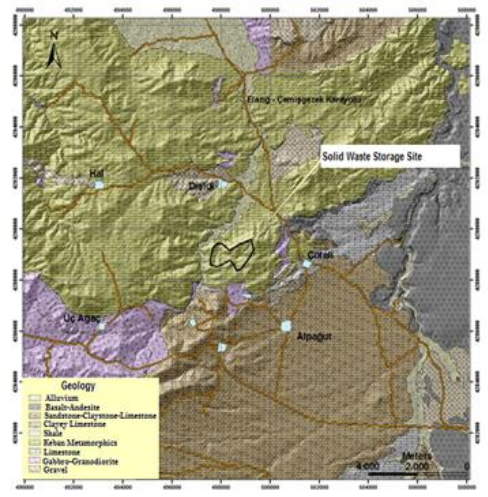

Figure 6: The geological map of the solid waste storage area. 


\subsection{Slope}

Slope is one of the main parameters for selecting solid waste storage sites [12],[23]. Land sites with more than $20 \%$ slopes are not suitable for solid waste landfill because of relatively high transportation and initial construction costs [32],[36]. The main reason for high construction costs is due to drainage systems needed for rain waters running downslope and seepages into waste storages. In the literature, it is emphasized that plains and relatively low sloping areas (about 8-12\%) are more preferable as waste storing sites [16],[20]. In this study, lands with less than $15 \%$ slope are classified as convenient and vice versa (Table 3). As the slope map in Figure 7 constructed by GIS tools indicates almost half of the study area has slopes more than $15 \%$ meaning that a major part of the selected site may not be convenient for waste disposing.

\section{$3.7 \quad$ Aspect}

The Turkish Regulation of Solid Waste Disposal in Sanitary Landfills requires that residential areas should not be influenced by harmful smells from solid wastes [33]. Therefore, the prevailing wind directions across the storage area have to be determined beforehand. The analysis of the meteorological data received from the General Directorate of State Meteorology Works of Turkey revealed that the north and northwest wind directions are more dominant across the study area. Hence, as compared to other wind directions they were assigned relatively higher scores (Table 3 ). The spatial map of aspect was created by GIS tools as presented in Figure 8. Here, the slopes are predominantly in the directions of west and

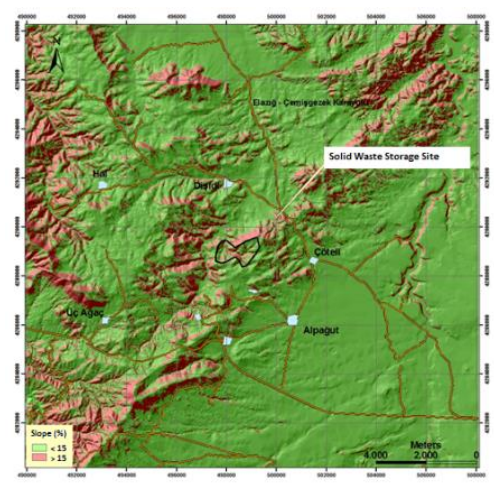

Figure 7: The slope map of the solid waste storage area.

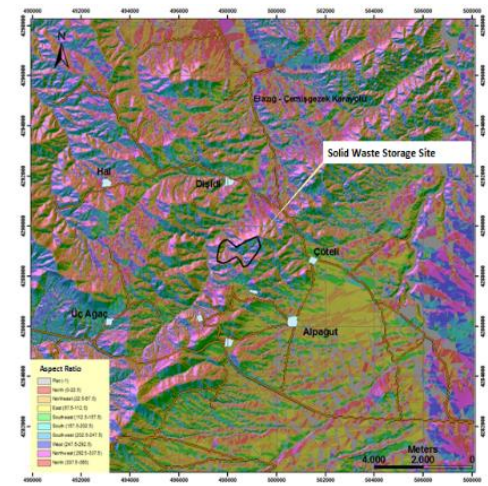

Figure 8: The aspect map for the solid waste storage area. northwest to be subject to relatively higher wind effects. This simply means the selected area is not convenient for solid waste disposal.

\subsection{Land capability classification}

Agricultural lands in Turkey are separated into eight different classes according to their soil, topography and drainage characteristics. In this study, Class I and II lands are given high scores (10 and 5, respectively), while the remaining is given zero score (Table 3 ). In Turkey, the construction of solid waste storage facilities in fertile lands are strictly forbidden by state laws and regulations [3]. The land classification map obtained by GIS is displayed in Figure 9 indicating that the selected site is located in Class III agricultural land and suitable for solid waste disposal.

\subsection{Land use}

Land uses such as pastures, forests and plantations are taken into consideration when determining the suitability indices [37]. Fertile agricultural lands (e.g., irrigated farms) are not considered as waste disposal sites [23]. The land use classification for the selected waste storage area is accordingly carried out as shown in Table 3 where the highest score is assigned to orchards and irrigated farm lands. The land use map for the study area was produced from the Corine classification maps [38], which are based on the interpretation of aerial/spatial photographs, and transformed into the raster format (Figure 10). As shown in the figure, the selected area is located in a sparsely vegetated area and, therefore, it is found to be convenient for solid waste disposal.

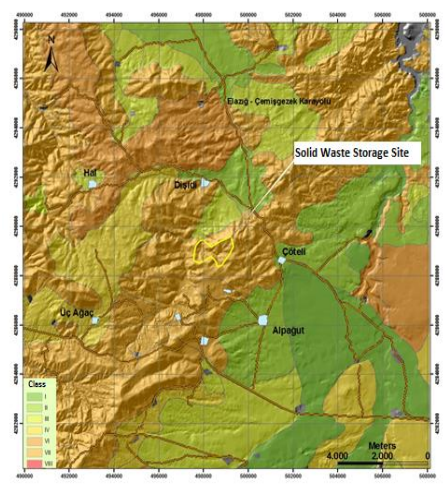

Figure 9: The land classification map for the solid waste storage area.

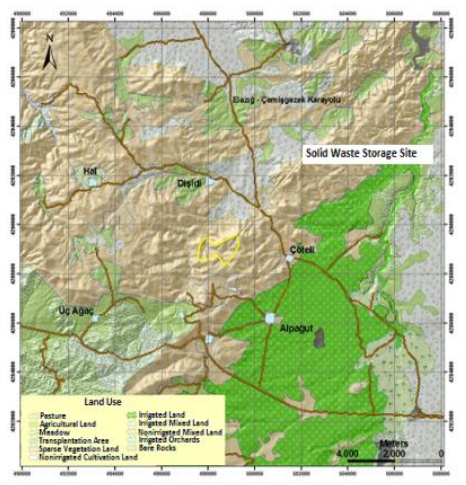

Figure 10: The land use map for the solid waste storage area. 


\section{Results and discussions}

The intercomparison matrix was constituted to calculate the normalized weightings of the criteria and specify their priority values as in Table 4 . Here, $\lambda_{\text {maks }}$ was found to be 9.38 which is close the matrix dimension (i.e., a 9x9 matrix). CR was calculated as 0.03276 which is far less than 0.1 and close to zero indicating the consistency of the intercomparison matrix as discussed above. As shown from the table, distance from residential areas and distance from rivers have relatively higher normalized weighting values, while aspect and land use have relatively lower values.

Figure 11 displays the resulting map for suitability analysis of the selected solid waste landfill site. The overlay analysis tool of ArcGIS 9.3 was employed to create this map with the use of individual maps prepared for each criterion. The analysis results indicate that the LSI values range from 2.64 to 6.10 for the Elazı $\breve{g}$ solid waste storage site. As shown in the figure, almost the entire area has relatively low LSI values implying that the selected site is suitable for solid waste disposal. However, just a tiny part in the south has a relatively high LSI value due mainly to high flood risks as discussed in Section 3.3.

\section{Conclusions}

In this study, a suitability analysis was carried out for selecting the solid waste landfill site in the city of Elazı $\breve{g}$, Turkey, with the use of Multi-Criteria Decision Analysis (MCDA) and Geographic Information Systems (GIS). The analysis results showed the landfill suitability index (LSI) values ranged from 2.64 to 6.10 (about $87 \%$ to $46 \%$, respectively) for the Elazıg solid waste landfill site. In other words, the suitability percentage of the site for solid waste disposal was found to vary between nearly 87 and 46. A similar study carried out by [39] in Mersin, Turkey, classified the suitability map as most suitable, suitable, moderately suitable, poorly suitable, least suitable, and completely unsuitable with their areal percentages. Overall, the relatively low LSI values in this study, indicated that the selected site was found suitable for solid waste disposal.

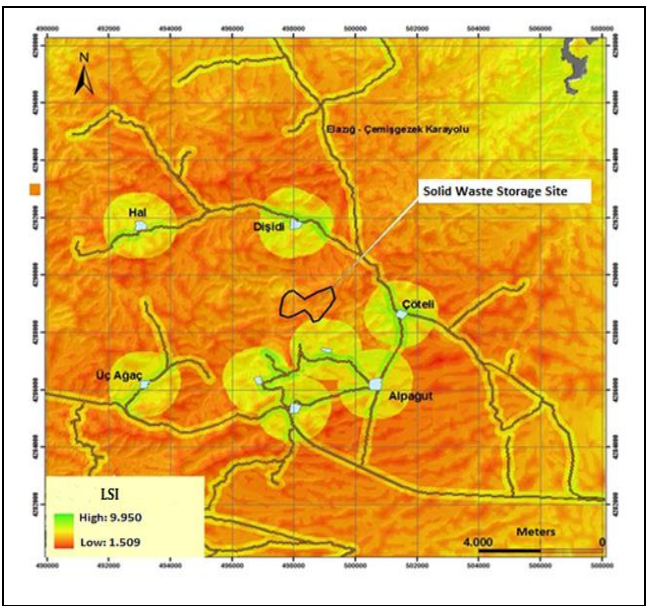

Figure 11: The landfill suitability index map for the solid waste storage area.

\section{References}

[1] Linkov I, Varghese A, Khurshid S, Seager TP, Kiker GA, Bridges T. Multi-Criteria Decision Analysis: A Framework for Structuring Remedial Decisions At Contaminated Sites. Editors: Linkov I, Ramadan A. Comparative Risk Assessment and Environmental Decision Making, 15-54, New York, NY, USA, Springer-Verlag New York Inc., 2004.

[2] Mozafar SM, Hadidi M, Vessali E, Mosstafakhani P, Taheri K, Shahoief S, Khodamoradpour M. "Integrating multicriteria decision analysis for a GIS-based hazardous waste landfill siting in Kurdistan Province, western Iran". Waste Management, 29(10), 2740-2758, 2009.

Table 4: Normalized weighting values for the selected criteria.

\begin{tabular}{|c|c|c|c|c|c|c|c|c|c|c|}
\hline Criterion & 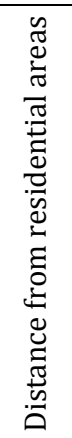 & 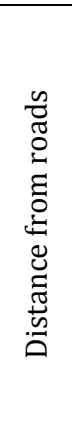 & 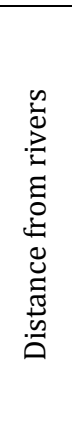 & 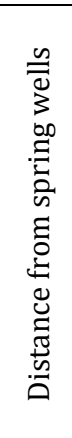 & $\begin{array}{l}\overrightarrow{0} \\
\stackrel{0}{0} \\
\stackrel{d}{0}\end{array}$ & $\frac{\Xi}{a}$ & 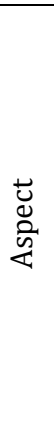 & 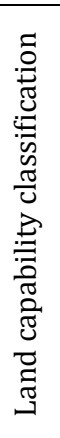 & 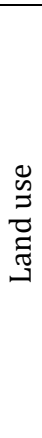 & 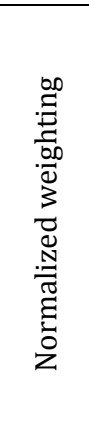 \\
\hline Distance from residential areas & 1 & & & & & & & & & 0.254 \\
\hline Distance from roads & $1 / 3$ & 1 & & & & & & & & 0.176 \\
\hline Distance from rivers & 1 & 1 & 1 & & & & & & & 0.225 \\
\hline Distance from spring wells & $1 / 3$ & $1 / 3$ & $1 / 3$ & 1 & & & & & & 0.096 \\
\hline Geology & $1 / 5$ & $1 / 5$ & $1 / 5$ & $1 / 5$ & 1 & & & & & 0.039 \\
\hline Slope & $1 / 3$ & 1 & $1 / 3$ & 1 & 3 & 1 & & & & 0.108 \\
\hline Aspect & $1 / 9$ & $1 / 9$ & $1 / 9$ & $1 / 3$ & $1 / 3$ & $1 / 5$ & 1 & & & 0.017 \\
\hline Land capability classification & $1 / 5$ & $1 / 5$ & $1 / 5$ & $1 / 3$ & 1 & $1 / 3$ & 5 & 1 & & 0.044 \\
\hline Land use & $1 / 9$ & $1 / 9$ & $1 / 9$ & $1 / 3$ & 1 & $1 / 3$ & 5 & 1 & 1 & 0.036 \\
\hline
\end{tabular}

$\lambda_{\text {maks }}=9.38 ; \mathrm{CI}=0.0475 ; \mathrm{RI}=1.45 ; \mathrm{CR}=0.03276$. 
[3] Nas B, Cay T, Iscan F, Berktay A. "Selection of MSW landfill site for Konya, Turkey using GIS and multi-criteria evaluation". Environmental Monitoring and Assessment, 160, 491-500, 2010.

[4] Baban SJ, Flannagan J. "Developing and implementing GISassisted constraints criteria for planning landfill sites in the UK". Planning Practice and Research, 13(2), 139-151, 1998.

[5] Gbaniea SP, Tengbe PB, Momoh JS, Medo J, Kabba VTS. "Modelling landfill location using Geographic Information Systems (GIS) and Multi-Criteria Decision Analysis (MCDA): Case study Bo, Southern Sierra Leone". Applied Geography, 36, 3-12, 2013.

[6] Moeinaddini M, Khorasani N, Danehkar A, Darvishsefat AA, Zienalyan M. "siting MSW landfill using weighted linear combination and analytical hierarchy process (AHP) methodology in GIS environment (case study: Karaj)". Waste Management, 30(5), 912-920, 2010.

[7] Şener Ş, Şener E, Nas B, Karagüzel R. “Combining AHP with GIS for landfill site selection: A case study in the Lake Beyșehir catchment area (Konya, Turkey)". Waste Management, 30(11), 2037-2046, 2010.

[8] Usman AA, Kumar M. "Site suitability analysis for waste disposal in Kano Metropolis, Nigeria (using multi-criteria evaluation, AHP, and GIS techniques)". International Journal of Scientific and Engineering Research, 6(11), 1072-1081, 2015.

[9] Khan D, Samadder SR. "A simplified multi-criteria evaluation model for landfill site ranking and selection based on AHP and GIS". Journal of Environmental Engineering and Landscape Management, 23(4), 267-278, 2015.

[10] Yildirim U, Guler C. "Identification of suitable future municipal solid waste disposal sites for the Metropolitan Mersin (SE Turkey) using AHP and GIS techniques". Environmental Earth Sciences, 75(2), 101-101, 2016.

[11] Bilgilioğlu SS. "Selection of suitable site for municipal solid waste disposal sites for the Aksaray (Turkey) using AHP and GIS methods". The Journal of Scientific and Engineering Research, 4(11), 36-45, 2017.

[12] Şener Ş, Şener E, Nas B. "Selection of landfill site using GIS and multi-criteria decision analysis for Beysehir Lake catchment area (Konya, Turkey)". Journal of Engineering Science and Design, 1(3), 134-144, 2011.

[13] Malczewski J. Propagation of Errors in Multi Criteria Allocation Analysis: A case study. Editors: Fandel G, Gal T. Multiple Criteria Decision Making, Berlin, 154-155, Springer, 1997.

[14] Vucijak B, Kurtagic SM, Silajdzic I. "Multicriteria decision making in selecting best solid waste management scenario: a municipal case study from Bosnia and Herzegovina". Journal of Cleaner Production, 130, 166-174, 2016.

[15] Qazi WA, Abushammala MFM, Azam MH. "Multi-Criteria Decision Analysis of Waste-To-Energy Technologies for Municipal Solid Waste Management in Sultanate of Oman". Waste Management and Research, 36(7), 594-605, 2018.

[16] Şener B. Landfill Site Selection by Using GIS. MSc Thesis, Middle East Technical University, Ankara, Turkey, 2004.

[17] Eldi N, Sui D. "A COM-based spatial decision support system for industrial site selection". Journal of Geographic Information and Decision Analysis, 7(2), 72-92, 2003.
[18] The Municipality of Elazı̆g (The Department of Environment Protection and Control). http://www.projeelazig.com/proje.php?id=54 (25.02.2018).

[19] Gedik F. Constituting an integrated waste management for the city of Elazığ (in Turkish). MSc Thesis, Namık Kemal University, Edirne, Turkey, 2008.

[20] Siddiqui MZ, Everett JW, Vieux BE. "Landfill siting using geographic information systems: A demonstration". Journal of Environmental Engineering, 122(6), 515-523, 1996.

[21] Muttiah RS, Engel BA, Jones DD. "Waste disposal site selection using GIS based simulated annealing". Computers and Geosciences, 22(9), 1013-1017, 1996.

[22] Zamoranoa M, Molerob E, Hurtado A, Grindlayb A, Ramos A. "Evaluation of a municipal landfill site in Southern Spain with GIS-aided methodology". Journal of Hazardous Materials, 160, 473-481, 2008.

[23] Kontos TD, Komilis DP, Halvadakis CP. "Siting MSW landfills with spatial multiple criteria analysis methodology". Waste Management, 25, 818-832, 2005.

[24] Sadek S, El-Fadel M, Freiha F. "compliance factors within a GIS-based frame work for landfill siting". Journal of Environmental Studies, 63(1), 71-86, 2005.

[25] Saaty TL. Analytical Planning, RSW Publications, 1985.

[26] Wang G, Qin L, Li G, Chen L. "Landfill site selection using spatial information technologies and AHP: A case study in Beijing, China". Journal of Environmental Management, 90(8), 2414-2421, 2009.

[27] Burnaz S, Topcu YI. "A multiple-criteria decision-making approach for the evaluation of retail location". Journal of Multi-Criteria Decision Analysis, 14, 67-76, 2006.

[28] Bollinger D, Pictet J. "Multiple criteria decision analysis of treatment and land-filling technologies for waste incineration residues". Omega, 36(3), 418-428, 2008.

[29] Barredo IJ, Sendra JB. "Comparison of multi-criteria evaluation methods integrated in Geographical Information Systems to allocate urban areas". Geographical Systems, 125, 313-327, 1999.

[30] Rezaei-Moghaddam K, Karami E. "A multiple criteria evaluation of sustainable agricultural development models using AHP". Environment, Development and Sustainability, 10, 407-426, 2008.

[31] The Ministry of Environment and Forestry of Turkey (The General Directorate of Environment Management). "The Criteria Check List for Waste Disposal Site Selection (in

Turkish)". https://webdosya.csb.gov.tr/db/destek/editordosya/Du zenli_Depolama_Tesis_Saha_Yon_ve_isletme_kilavuzu.pdf (15.07.2014)

[32] Lin HY, Kao JJ. "Enhanced spatial model for landfill siting analysis". ASCE Journal of Environmental Engineering, 125, 845-851, 1999.

[33] The Regulation for Sanitary Disposal of Wastes (in Turkish). "The Official Gazette, No: 27533". http://www.resmigazete.gov.tr/eskiler/2010/03/20100 326-13.htm (25.02.2018).

[34] Şener B, Suzen ML, Doyuran V. "landfill site selection by using Geographic Information Systems". Environmental Geology, 49, 376-388, 2006.

[35] Dorhofer G, Siebert H. "The search for landfill sitesrequirement sand implementation in lower Saxony, Germany". Environmental Geology, 35(1), 55-65, 1998. 
[36] Küçükönder M, Karabulut M. "A Study on site selection for waste storage in Kahramanmaraş with multi-criteria analysis method (in Turkish)". Geographic Sciences Journal, 5(2), 55-76, 2007.

[37] Kontos TD, Komilis DP, Halvadakis CP. "Siting MSW landfills on Lesvos Island with a GIS-based methodology". Waste Management and Research, 21(3), 262-278, 2003.

[38] The CORINE Project. "The Ministry of Forestry and Water Management of Turkey". http://corine.ormansu.gov.tr/corineportal/turkiyecalism alar.html (24.02.2018).
[39] Yildirim U, Guler C. "Identification of suitable future municipal solid waste disposal sites for the Metropolitan Mersin (SE Turkey) using AHP and GIS techniques". Environmental Earth Sciences, 75(2), 101-101, 2016. https://doi.org/10.1007/s12665-015-4948-8. 